\title{
Relating Technology Education Goals to Curriculum Planning
}

\author{
Karen F. Zuga ${ }^{1}$
}

As representations of the aims, mission, and aspirations of industrial arts/technology educators, the written goals of the field have always prescribed a liberal educational role for industrial arts/technology education. Goal statements exceed the single goal of skill development and include such goals as helping students to become wise consumers and problem solvers and to understand industry and technology. Industrial arts/technology education goals have evolved over time. This evolution has reflected a drift towards more liberal education ideals with goals which specify the study of the relationships among industry, technology, and society, the interdisciplinary nature of the field, and general problem solving.

The practice of industrial arts/technology education, however, has not always demonstrated a clear relationship to those goal statements. Industrial arts/technology education laboratories and student activities often resemble vocational education laboratories and student activities. Moreover, much of the prescriptive theory of curriculum planning for industrial arts/technology education is technical in nature, relying upon curriculum planning techniques which are based upon behaviorism. A discontinuity exists in the descriptive theory (goal statements) and prescriptive theory (curriculum-planning practices) of industrial arts/technology education. This discontinuity is caused, in part, by the strategies used for planning curriculum and the limited prescriptive theory which exists in the field.

Identifying alternative curriculum-planning processes could have a sizeable influence on the future of technology education. If teachers were able to know and to use curriculum planning processes which are compatible with the goals they choose to implement, then the congruence between the goals and practices of technology education should improve. This is especially critical for a subject matter which is in a state of transition. Learning about a variety of curriculum designs and processes would result in a more informed technology education teacher, capable of making more accurate curriculum decisions. Accurate decisions about content and the presentation of that content should result in observable differences in the conduct of technology education.

The goals of industrial arts in the beginning of this century were more restricted and less varied than recent goal statements referring to technology education. Furthermore, as the goals of technology education have changed, the priorities of technology education have changed also. These changes reflect a mission of technology education which differs from the mission of industrial arts education at the beginning of the century. Written curriculum documents, compared over a period of years, reflect an addition of goals and a repositioning of goal statements which represents a theoretical shift. Tracking that shift is difficult because of the involvement of numerous people and agencies, such as specific authors, state departments of education, and school committees. Nonetheless, by looking at specific examples of the general trend, educators can see both the addition of new goals and a change in the priority of goals for technology education. Documents which synthesize goals from selected time periods of approximately 20 year increments can illustrate this shift.

Early industrial arts goals included statements about career exploration and vocation, consumerism, and skill development and heavily emphasized the purpose of the subject matter as prevocational study. Recent technology education goals reflect an increased emphasis on the study of industry and technology, critical consumerism, and the development of intellectual processes and interpersonal behavioral skills. Essentially, industrial arts and technology education goals can be grouped into the following seven cate-

1 Karen Zuga is Assistant Professor, The Ohio State University, Columbus, Ohio.

The author is indebted to the following people who worked on this project: James LaPorte, Co-Investigator; Michael Scott, Consultant; Tsang Liang, Graduate Research Assistant; and Kuang Yu, Graduate Research Assistant.

This project was the result of a grant from The Office of Vocational and Adult Education, U. S. Department of Education. However, the opinions expressed herein do not necessarily reflect the position or policy of the $U$. S. Department of Education, and no official endorsement by the U. S. Department of Education should be inferred. 
gories: physical development, career exploration and vocation, intellectual processes, skill development, critical consumerism, industry and technology, and integration of the disciplines. Physical development refers to largely historical goals of the field which represent the effort to improve motor control and coordination through tool instruction, but not for the purpose of skill development in the use of tools. Career exploration and vocational goals are concerned with preparing students for either entry into an occupation or entry into vocational education programs by providing exploratory activities which can be developed for avocational purposes in many occupational areas. Intellectual processes refer to those goals which develop critical thinking and problem solving ability, in addition to other processes which emphasize working together, communicating effectively, and taking leadership roles. Skill development goals point to the specific instruction and perfection of the ability to use tools, machines, and processes. Critical consumerism goals address the relationship of industrial arts/technology education to society through a variety of efforts, including the ability to be a wise consumer and a technologically literate citizen. Industry and technology goals are those which specify the study of industry and technology as a subject. Finally, the integration of the disciplines are those goals which provide for the relationship of industrial arts/technology education to other disciplines, fields of study, and subject matter.

In 1928 Warner did an extensive study about the goals of industrial arts by looking at books, courses of study, periodicals, government bulletins, and the annual reports of the National Education Association. These goals reflect a traditional view of industrial arts highlighting career exploration and vocation, consumerism, and skill development. The vestiges of the influence of Woodward's (1898) version of manual training are evident in the goal of developing fine motor control. Some of the goals were as follows:

Career Exploration and Vocation: exploratory shop and drawing courses for the detection, discovery, or tryout of interests and aptitudes; avocational and prevocational purposes, preparing for a future industrial occupation;

Critical Consumerism: making more intelligent choosers and users of the products of industry;

Skill Development: develop household mechanics; develop mechanical intelligence through experience in hand work where fairly high levels of skill in the use of various tools and materials are the chief emphasis; Physical Development: develop coordination of "hand and eye" by making things.

A 1948 text by Newkirk and Johnson listed goals for industrial arts. By this time, the concern for developing motor control was dropped as a goal, but the major goals of career exploration and vocation, consumerism, and skill development continued, in addition to new goals in the intellectual processes and the integration of disciplines. These goals were influenced by the philosophy of the time period and reflected the earlier influence of the "Cardinal Principles" of secondary education generated by the Commission on the Reorganization of Secondary Education (1918), and the more recent influence of the National Education Association's Educational Policies Commission report (1937). Industrial arts was also growing into a specifically secondary education subject and reflected the prevocational emphasis necessary in a society in which a high school diploma was the terminal educational program for a majority of its members. The following are some of Newkirk and Johnson's goals:

Intellectual Processes: develop social understanding and the ability to work in groups; develop the ability to plan and complete projects;

Integration of the Disciplines: provide a medium for expression in mathematics, science, language arts, and social science;

Career Exploration and Vocation: give experiences that will increase understanding of modern industry and that will lay the foundation for and help determine vocational interests; avocational purposes; Critical Consumerism: develop the ability to recognize quality and design in the products of industry; Skill Development: use a variety of tools and construction materials in a workmanlike manner; develop the ability to read and make working drawings, charts, and graphs; and develop the ability to maintain and service the common products of industry in a safe and efficient manner.

By the 1960's, industrial arts goals began to reflect a greater concern for the study of industry and technology in addition to maintaining many of the previous goals. Perhaps industrial arts educators began to be influenced by the study of the disciplines movement in curriculum. In a 1967 textbook, Wilber and Pendered summarized industrial arts goals in the following way:

Industry and Technology: explore industry and American industrial civilization; Intellectual Processes: develop critical thinking related to industry and industrial materials; develop desirable social relationships; 
Career Exploration and Vocation: provide information and experiences in order that students may choose a future vocation; develop recreational and avocational activities;

Critical Consumerism: increase appreciation for good craftsmanship and design; increase consumer knowledge for the purpose of selecting, buying, and using the products of industry;

Skill Development: develop safe working practices and develop a degree of skill.

Because of the lack of contemporary teacher education texts about technology education goals and studies which synthesize those goals, a recent effort to achieve consensus in the field through the Jackson's Mill project and the resulting implementation guide (American Technical Foundation, undated) will serve as the model for technology education goals. They include the following:

Industry and Technology: appreciate the evolution of industry and technology;

Critical Consumerism: establish values on the impact of industry and technology and how it alters our environment; develop human potentials for responsible work, leisure, and citizenship roles in a technological society.

Skill Development: develop knowledge and ability to properly use the tools, techniques, and resources of industrial and technological systems;

Intellectual Processes: develop creative solutions to present and future societal problems using technical means; and

Career Exploration and Pre-Vocation: develop human potentials for responsible work, leisure, and citizenship roles in a technological society (pp. 9-10).

Just as Warner's (1928) identified goals reflected the influence of manual training, current goals for technology education reflect the influence of industrial arts goals. Even with the influence of tradition, a shift in the emphasis of industrial arts/technology education goals may be observed. More emphasis is being put on the subjects of industry and technology, the teaching of cognitive and affective intellectual processes, and the role of consumerism, which is represented as a critical preparation for citizenship. Many of the goals listed in current technology education plans, including the goals from the American Technical Foundation, appear to include a greater emphasis on the relationship of industry, technology, and society. The interest in identifying the history of technology and creating not just good consumers of industrial products, but also responsible citizens with respect for the environment, signals a change in the direction of the goals of the subject matter. In addition, as time has passed, statements about the value of problem solving have changed from simple statements about the ability to plan and construct projects to more global statements about the role of problem solving in society. Table 1 illustrates this gradual shift in industrial arts/technology education goals.

These goals represent what selected industrial arts/technology educators believe to be important about the subject matter. They do not necessarily reflect the actual practice of industrial arts/technology educators. Just what is happening in the classrooms and laboratories of technology education is, perhaps, a very different picture. The most comprehensive and current information about this comes from a study (Bame and Miller, 1980) that identified and created standards for industrial arts in the early 1980's. Data from this study indicated that teachers at that time listed "skill in tools and machines" and "technical knowledge and skill" (p. 15) as the two most important goals of industrial arts education. Even though the name of the subject matter has been changed in most states since that time, one cannot count on the philosophy of teachers to have changed without evidence of it. The Bame and Miller study also identified more contemporary purposes. Purposes such as "develop an understanding of the nature and characteristics of technology" and "understand the application of science and mathematics" (p. 15) were ranked last in positions eleven and twelve respectively by industrial arts teachers.

This discrepancy in ranking goals reflects discontinuity between the practice and goals of technology education. This discrepancy is caused, in part, by the curriculum planning practices in technology education and vocational education. Vocational education has influenced and continues to influence technology education. There has been an historical relationship among technology educators and vocational educators in universities, state departments of education, and federal guidelines for vocational education. Prescriptive curriculum theory in vocational education and technology education relies upon a technical curriculum design.

\section{Curriculum Designs and Prescriptive Theory}

Curriculum design refers to the way the subject matter is conceptualized and its major components are arranged, in order to provide direction for curriculum development (Ornstein \& Hunkins, 1988). When curriculum designs are categorized, the prescriptive literature of industrial arts/technology education can 
Table 1

Evolution of Industrial Arts/Technology Education Goals

Categories of Goals $\neg$ Twenty Year Time Periods

$\neg 1928 \neg 1948 \neg 1967 \neg 1980$ 's

Physical Development $\neg X$

Integration of Disciplines $\neg \neg X$

Intellectual Processes $\neg \neg X \neg X \neg X$

Career and Vocation $\neg X \neg X \neg X \neg X$

Critical Consumerism $\neg X \neg X \neg X \neg X$

Skills Development $\neg \mathrm{X} \neg \neg \neg \neg \mathrm{X}$

Industry and Technology $\neg \neg \neg \mathrm{X} \neg \mathrm{X}$

be fit into those categories for the purpose of analyzing trends in theory. This categorization further emphasizes the discontinuity between the goals of technology education and the prescriptions for curriculum planning.

\section{Curriculum Designs}

A number of curriculum texts and papers focus on curriculum designs. In one of the early attempts to categorize curriculum designs, Eisner and Vallance (1974) identified five orientations toward curriculum: academic rationalism, the development of cognitive processes, curriculum as technology, selfactualization, and social reconstruction-relevance. McNeil (1977) introduced four curriculum designs: humanistic, social reconstructionist, technological, and academic subject curriculum. Later, Eisner (1979) described five basic orientations toward curriculum: academic rationalism, personal relevance, social adaption and social reconstruction, curriculum as technology, and development of cognitive processes. Joyce (1980) provided four models for curriculum design: social interaction, information/processing, personal, and behavior modification and cybernetic models. Saylor, Alexander, and Lewis (1981) appeared to have achieved a temporary synthesis with the five designs: subject matter/disciplines, specific competencies/technology, human traits/processes, social functions/activities, and individual needs and interests/activities. Six categories were created by Wiles and Bondi (1984): conservative liberal arts, educational technology, vocational, humanistic, social reconstruction, and deschooling. In 1986, Schubert expanded the list to eight categories of designs: content or subject matter, cultural reproduction, learning outcomes, discrete tasks, social reconstruction, activities, experience, and currere. Recently, Ornstein and Hunkins (1988) grouped a total of eleven designs into three categories. These categories and designs are 1) subject-oriented designs: subject, discipline, broad fields, and correlation; 2) learner-centered designs: experience-centered, romantic (radical), child-centered, and humanistic; and 3) problem-centered designs: life-situation, core (social functions) and social problems, and reconstructionist.

In order to understand curriculum designs it is helpful to group the varying conceptions into broad categories and discuss the different designs suggested by the above authors within these categories. Many of the various names and descriptions of curriculum designs appear to be similar. For the purposes of discussion, the chart in Table 2 helps to organize curriculum designs into five major categories. Although some authors have suggested more than five designs, most of the designs can be included in the following five major categories: academic, technical, intellectual processes, social, and personal.

Academic. Academic curriculum designs tend to focus on a body of knowledge which is grouped into disciplines, subject matter, or broad fields. It is a familiar pattern of organization that is evident in the way in which knowledge is organized for course work in most schools. Besides being a means of designing curriculum, the academic design carries with it the message that knowledge is organized into logical categories and that values can be attached to those categories. For example, the academic rationalism conception of curriculum created by Eisner and Vallance (1974) illustrates this design. Selected content, such as the basic subjects in the liberal arts, is held to be the central purpose of schooling and the curriculum. These subjects, through a disciplinary organization of content, focus the curriculum. Often, academic rationalism as an ideology influences issues in education such as the "back to the basics" movement. Those who promote these designs identify particular subject matter which is designed to transmit the heritage of a culture through literature, history, science, and other fundamental disciplines.

In technology education, current curriculum proposals which focus on technology as the basis of content and also focus on taxonomies of technological concepts reflect an academic curriculum design. 
Table 2

Synthesis of Curriculum Designs

\begin{tabular}{|c|c|c|c|c|c|}
\hline $\begin{array}{l}\text { Eisner \& } \\
\text { Vallance } \\
\text { (1974) }\end{array}$ & $\begin{array}{l}\text { Academic } \\
\text { Rationalism }\end{array}$ & $\begin{array}{l}\text { Curriculum } \\
\text { as Technol- } \\
\text { ogy }\end{array}$ & $\begin{array}{l}\text { Development } \\
\text { of Cognitive } \\
\text { Processes }\end{array}$ & $\begin{array}{l}\text { Social } \\
\text { Reconstruc- } \\
\text { tion/Relevance }\end{array}$ & $\begin{array}{l}\text { Self- } \\
\text { Actualization }\end{array}$ \\
\hline $\begin{array}{l}\text { McNeil } \\
\text { (1977) }\end{array}$ & $\begin{array}{l}\text { Academic } \\
\text { Subject }\end{array}$ & Technological & & $\begin{array}{l}\text { Social } \\
\text { Reconstruc- } \\
\text { tionist }\end{array}$ & Humanistic \\
\hline $\begin{array}{l}\text { Eisner } \\
(1979)\end{array}$ & $\begin{array}{l}\text { Academic } \\
\text { Rationalism }\end{array}$ & $\begin{array}{l}\text { Curriculum as } \\
\text { Technology }\end{array}$ & $\begin{array}{l}\text { Development } \\
\text { of Cognitive } \\
\text { Processes }\end{array}$ & $\begin{array}{l}\text { Social } \\
\text { Adaptation } \\
\text { and Recon- } \\
\text { struction }\end{array}$ & $\begin{array}{l}\text { Personal } \\
\text { Relevance }\end{array}$ \\
\hline $\begin{array}{l}\text { Joyce } \\
(1980)\end{array}$ & & $\begin{array}{l}\text { Behavior } \\
\text { Modification } \\
\text { Cybernetic }\end{array}$ & $\begin{array}{l}\text { Information } \\
\text { Processing }\end{array}$ & $\begin{array}{l}\text { Social } \\
\text { Interaction }\end{array}$ & Personal \\
\hline $\begin{array}{l}\text { Saylor, } \\
\text { Alexander } \\
\text { \& Lewis } \\
(1981)\end{array}$ & $\begin{array}{l}\text { Subject } \\
\text { Matter/ } \\
\text { Disciplines }\end{array}$ & $\begin{array}{l}\text { Specific } \\
\text { Competencies/ } \\
\text { Technology }\end{array}$ & $\begin{array}{l}\text { Human Traits } \\
\text { Processes }\end{array}$ & $\begin{array}{l}\text { Social Func- } \\
\text { tions/Activities }\end{array}$ & $\begin{array}{l}\text { Individual Needs } \\
\text { \& Interests/ } \\
\text { Activities }\end{array}$ \\
\hline $\begin{array}{l}\text { Wiles \& } \\
\text { Bondi } \\
\text { (1984) }\end{array}$ & $\begin{array}{l}\text { Conservative } \\
\text { Liberal Arts }\end{array}$ & $\begin{array}{l}\text { Educational } \\
\text { Technology } \\
\text { \& Vocational }\end{array}$ & & $\begin{array}{l}\text { Social } \\
\text { Reconstruc- } \\
\text { tion }\end{array}$ & $\begin{array}{l}\text { Deschooling } \\
\text { \& Humanistic }\end{array}$ \\
\hline $\begin{array}{l}\text { Schubert } \\
\text { (1986) }\end{array}$ & $\begin{array}{l}\text { Subject } \\
\text { Matter }\end{array}$ & $\begin{array}{l}\text { Learning } \\
\text { Outcomes \& } \\
\text { Discrete Tasks }\end{array}$ & & $\begin{array}{l}\text { Social } \\
\text { Reconstruc- } \\
\text { tion, Activities, } \\
\text { \& Cultural } \\
\text { Reproduction }\end{array}$ & $\begin{array}{l}\text { Experience } \\
\& \text { Currere }\end{array}$ \\
\hline $\begin{array}{l}\text { Ornstein \& } \\
\text { Hunkins } \\
\text { (1988) }\end{array}$ & $\begin{array}{l}\text { Subject } \\
\text { Centered }\end{array}$ & & & $\begin{array}{l}\text { Problem } \\
\text { Centered }\end{array}$ & $\begin{array}{l}\text { Learner } \\
\text { Centered }\end{array}$ \\
\hline $\begin{array}{l}\text { Primary } \\
\text { Focus }\end{array}$ & Academic & Technical & $\begin{array}{l}\text { Intellectual } \\
\text { Processes }\end{array}$ & Social & Personal \\
\hline
\end{tabular}

One of the first and best examples of this design was created in 1964 by DeVore, with the construction of taxonomies similar to the taxonomies of plant and animal life forms. From this early work, DeVore and his followers have continued to pursue the design of an academic curriculum for technology education. The academic design refers to organizing the concepts of the discipline or subject matter in a way that is very different from the technical design of organizing performance or behavioral objectives. The concepts of a subject such as technology education are identified for the purpose of generating constructs which cut across traditional skills and processes.

Technical. This design of the curriculum is based upon an analysis of performance or processes. A job and task analysis or the identification and sequencing of behavioral outcomes becomes the means for creating curriculum. Efficiency is desired, requiring the curriculum to provide the most efficient means of delivering the identified performance objectives. Objectives, or outcomes based on task and process sequencing, become the organizing elements of the curriculum rather than the taxonomy of content one might find in the academic design. These designs are highly structured, and whether they are derived from task analyses or systems (inputs, processes, outputs) analysis, they are behavior-focused curriculum plans. Tyler (1949) is often credited with initiating this curriculum design with the course syllabus, Basic Principles of Curriculum and Instruction. However, others such as Bloom, Mager, and Popham have added much to his original work.

The technical design was influenced by the popularity of behavioral psychology during the middle of this century. This influence has resulted in the incorporation of devices such as teaching machines and computers to deliver programmed lessons. Often, there is a high degree of structure involved in technical designs no matter what or who delivers the lesson. Technical designs have been extremely popular in vocational education where one of the major objectives of the curriculum is to prepare people to function 
in specific jobs. The vocational methods of analysis and delivery lend themselves to detailing the tasks of a job and organizing curriculum and instruction with specific performance objectives in mind.

Traditional vocational education efforts in trade and industrial education best illustrate a technological design of curriculum. Vocational curricula are created with task analyses and are structured to provide the student with a sequenced series of learning steps. The curriculum planning recommendations of Allen, Selvidge, and Fryklund (Allen, 1919; Selvidge, 1923; Selvidge and Fryklund, 1946; \& Fryklund, 1956 \& 1970) are excellent examples of a technical approach to developing curriculum.

A second effort serves as an industrial technology education example of technical design. Using systems to analyze content in 1966, Towers, Lux, and Ray organized the processes of industrial technology in a conceptual document called A Rationale and Structure for Industrial Arts Subject Matter. In their subsequent textbooks, The World of Construction (1970) and The World of Manufacturing (1971), they further refined the technical design for curriculum in industrial technology education by focusing on the processes of manufacturing and construction and by structuring the teaching materials with student performance objectives. The processes served as tasks.

Intellectual Processes. The least frequently represented curriculum design deals with the development of cognitive processes. This design makes the development of either cognitive processes such as critical thinking and problem solving or human processes and traits such as creativity and self-confidence the focus of curriculum, rather than a structured discipline or a sequenced task. The goal of this design is to increase learning efficiency and the transfer of problem solving abilities to all areas of the curriculum and life. Emphasis on processes has recently been increased through current research on students' cognition and metacognition. The emphasis in this design is on such processes as problem solving, first, and then on the context and content of the learning situation. Current research about cognition reveals the importance of the context and content of the activity, in addition to factors associated with the student such as prior knowledge with respect to intellectual processes.

Clear-cut examples of process curricula are difficult to identify. Recent thinking skills curricula which have been developed as separate courses or as subject-matter-specific programs in the social studies and language arts are the best examples of curriculum which are designed with a clear focus on intellectual processes to the exclusion (or relegation to lesser consideration) of content. In technology education, examples of intellectual processes curriculum designs often appear in design courses. In these courses, the instructor identifies a problem solving model as the basis of subject matter and particular activities related to industry and technology for improving or teaching about critical thinking and problem solving. These activities, similar to the activities one would find in an Odyssey of the Mind competition, are examples of an emphasis of intellectual processes within a subject matter.

Social. This design focuses on the application of knowledge in realistic or real world situations. A variety of assumptions may contribute to this design with some mutual exclusivity to the assumptions. In brief, there are two distinct and opposite sides to this design. For example, one variation of the design could focus on social reconstruction with the assumption that the future of society can be changed as a result of the educational activities of the current generation. This assumption leads to a curriculum plan which would focus on providing students with opportunities to work on social projects for the purposes of changing their environment. On the other hand, the social design could also focus on social adaptation with the assumption that students are the raw material of society, and they need to be shaped to conform to existing social values. In this variation, a social design takes the opposite direction with respect to students, society, and the future by focusing on the information students need in order to fit into adult society.

Examples of social reconstruction (changing society) assumptions are in the work of Dewey, Counts, and others of the Reconstructionist Era during the beginning and middle of this century, and in the work of the contemporary reconceptualists such as Apple, Giroux, and Anyon. Social reconstruction is demonstrated in technology education curriculum when students take on such projects as auditing the energy use of their homes and school buildings and proceeding to improve the efficiency of energy use in those buildings. Reconstruction designs are often integrated with other curriculum designs.

Adaptation (conforming to society) assumptions are present in the early curriculum work of Bobbitt. These same assumptions are often a part of technical designs of vocational curriculum when the goal is to prepare students to fill selected roles in an occupation. Vocational education curricula often involve social adaptation by preparing students for occupations. Technology education fulfills this goal by creating manufacturing roles as workers on simulated assembly lines or by specifying the following of directions in project work.

Personal. Personal curriculum designs are learner-centered with a focus on the individual needs and interests of the student. Students help or totally create curriculum by expressing interests and investigating those interests. Teachers serve as diagnosticians and facilitators for this effort. It is the teacher's role to help students to identify interests and guide them to appropriate resources and connections to other 
knowledge. The autobiographical nature of curriculum as currere, a personal experience, and the desire to deschool society because of the rigidity of schools fit into personal curriculum designs. The curriculum writing of Friere illustrates the nature of personal involvement in curriculum. The goals of the personal design are to put the control and choice of the curriculum into the hands of the students instead of subject matter specialists and to allow students to personally integrate the information which they choose. This curriculum design is associated with the progressive education movement, and more recently, open schools.

The Maryland Plan (Maley, 1973) emphasizes a personal curriculum design. Within the context of a subject, industrial arts, this plan creates a way for students to regain control over the curriculum. Under the auspices of industrial arts education, the Maryland Plan focuses on allowing the students to choose topics of investigation within specified areas of study such as production and research and development. This particular curriculum plan is one of the few documents which illustrates a personal curriculum design in technology education. However, traditional industrial arts teachers in woodworking, drawing, and metalworking often integrated personal curriculum designs into their programs through the use of self- selected projects as a major vehicle of the curriculum.

\section{Curriculum Designs and Technology Education Goals}

Curriculum designs are not always mutually exclusive in practice. Often, several designs can influence the creation of specific curriculum. In addition, curriculum designs are directly related to the purposes, goals, and objectives of a specific curriculum. A knowledge of curriculum designs serves two purposes. It can be used as a framework for diagnosing the purpose of a curriculum or the ideology of a teacher, and it can help to create curriculum which operationalizes the desired goals.

Many of the goals of technology education point to varying designs of curriculum. This becomes clearer when the goals of technology education are equated with the five curriculum designs in an attempt to diagnose the orientation of the field (see Table 3).

When contemporary technology education goals are correlated with curriculum designs, the diversity of the goals becomes apparent. Technology education goals tend to incorporate all of the five curriculum designs. For example, all of the goals listed in the recent American Technical Foundation project (see Table 3) illustrate how they could fit into the curriculum designs. Goals such as "appreciate the evolution of industry and technology" may guide practitioners to design curriculum based upon a selection of content-an academic design. Skill development goals encourage the use of a technology design. The goal of developing "creative solutions to societal problems" indicates a relationship to the intellectual processes and social designs. Critical consumerism goals such as establishing "values on the impact of industry and technology on our environment" indicate a social design. Finally, the desire to "develop human potential for responsible work, leisure, and citizenship roles" relates to both the personal and social curriculum designs.

Contemporary technology education goals relate to all of the curriculum designs. It is particularly interesting to note that three of the goals relate either directly or indirectly to the social design, demonstrating an increased emphasis on the importance of this curriculum design to technology education. Moreover, the statements appear to reflect the social reconstruction viewpoint of the social design rather than the social adaptation viewpoint of that design. This appears to be a major shift in the orientation of technology education. The orientation of technology education goals could provide much direction for curriculum planning if teachers were given adequate information about how to distinguish and implement a variety of curriculum designs. If teachers receive little guidance and information or receive only information about a technical curriculum design, then curriculum plans will reflect a technical approach and will revert to skill development as the primary activity in the classroom.

The diversity of technology education goals and their relationship to the various curriculum designs leads to the conclusion that there are many ways to proceed with curriculum planning in technology education. Historically, variations of two major curriculum designs have been prescribed most often in the literature - the technical and the academic designs. Recent changes in technology education goals may require a reconceptualization of curriculum planning theory for technology educators.

\section{Planning Curriculum in Industrial Arts and Technology Education}

Curriculum designs can also be used to diagnose the advice that technology educators give about how to select content and plan curriculum for the field. As a review of historical and contemporary curriculum advice, authors' ideas are categorized and discussed according to the curriculum designs (see Table 4). Early textbooks were used for the historical review of curriculum planning prescriptions and, because of the lack of a current professional textbook about planning curriculum in technology education, journal articles and yearbook chapters from technology education sources are used for contemporary prescriptions. 
Table 3

Relationship of Technology Education Goals to Curriculum Designs

\begin{tabular}{ll}
\hline Curriculum Designs & Technology Education Goals* \\
\hline Academic & $\begin{array}{l}\text { Industry and Technology: appreciate the } \\
\text { evolution of industry and technology. }\end{array}$ \\
Technical & $\begin{array}{l}\text { Skill Development: develop knowledge and } \\
\text { ability to use tools, techniques, and resources of } \\
\text { industrial and technical systems. }\end{array}$ \\
Intellectual & $\begin{array}{l}\text { Intellectual Processes: develop creative } \\
\text { solutions to present and future societal problems } \\
\text { using technical means. }\end{array}$ \\
Social & $\begin{array}{l}\text { Critical Consumerism: establish values on the } \\
\text { impact of industry and technology and how it } \\
\text { alters our environment. }\end{array}$ \\
Personal & $\begin{array}{l}\text { Career Exploration and Vocation: develop } \\
\text { human potential for responsible work, leisure, and } \\
\text { citizenship roles in a technological society. }\end{array}$ \\
* Goals are taken from & Technical Foundation of America (undated) \\
curriculum guide. &
\end{tabular}

Although representation of each design can be found in the literature, most curriculum planning prescriptions in industrial arts/technology education have been and still are technical curriculum designs. Dominance of the technical design results in the increased chance of skill development as the primary outcome of industrial arts/technology education curriculum. Unquestioned acceptance of a technical curriculum design leads to a lack of attention to creating alternatives and a decreasing chance of providing alternative prescriptions. Technology education then could suffer from the same theory/practice discontinuity that industrial arts has endured.

The Dominant Technical Design. Prescriptions for curriculum planning increased after the turn of the century. Industrial and vocational educators contributed to prescriptions for planning curriculum and created some of the first texts for the purposes of teaching curriculum planning. Bobbitt's early curriculum book (1918) cites the work of vocational educators:

They talked with expert workmen; and observed the work-processes. In their report, for each occupation they present: (1) a list of tools and machines with which a workman must be skillful; (2) a list of the materials used in the work with which workers need to be familiar; (3) a list of the items of general knowledge concerning jobs and processes; (4) the kinds of mathematical operations actually employed in the work; (5) the items or portions of science needed for control of processes; (6) the elements of drawing and design actually used in the work; (7) the characteristics of the English needed where language is vitally involved in one's work, as in commercial occupations; (8) elements of hygiene needed for keeping one's self up to the physical standards demanded by the work; and (9) the needed facts of economics (p. 47).

The basic system of occupational analysis, task analysis, or job and trade analysis on which Bobbitt reported was developed through years of practice and recorded by Allen in 1919 in the text, The Instructor, The Man, and The Job. Bobbitt's book served as the first curriculum book for all educators, whereas Allen's became the first curriculum book for vocational educators, specifically industrial educators. Both books took a technical approach to curriculum design. By examining ends, the instructor was guided to codify and teach the means to achieve the desired end. Curriculum and instruction were to be sequenced logically and linearly and to be based upon observable ends such as job performance.

Because of the association of industrial educators, which includes vocational-industrial, industrial arts/technology, industrial and military training, and technical educators, particular subject areas such as industrial arts/technology education have shared many ideas, organizations, and, often, classrooms with 
Table 4

Curriculum Planning Recommendations Categorized

by Curriculum Designs

\begin{tabular}{|c|c|c|}
\hline Designs & Sub-designs & $\begin{array}{l}\text { Authors and Dates } \\
\text { of Recommendations }\end{array}$ \\
\hline Academic & & $\begin{array}{l}\text { DeVore, } 1964 \\
\text { McCrory, } 1980 \\
\text { Maley, } 1982 \\
\text { Yost, } 1988 \\
\text { Zuga, } 1988\end{array}$ \\
\hline \multirow[t]{3}{*}{ Technical } & $\begin{array}{l}\text { Task } \\
\text { Analysis }\end{array}$ & $\begin{array}{l}\text { Allen, } 1919 \\
\text { Selvidge, } 1923 \\
\text { Bollinger and Weaver,1955 } \\
\text { Fryklund, 1956, } 1970\end{array}$ \\
\hline & $\begin{array}{l}\text { System } \\
\text { Analysis }\end{array}$ & $\begin{array}{l}\text { Towers, Lux, and Ray, } 1966 \\
\text { Witherspoon, } 1976 \\
\text { Ritz, } 1980 \\
\text { Schwerkolt and Spontelli, } 1987 \\
\text { Wescott, } 1988 \\
\text { Jones, } 1988 \\
\text { Bjorklund, } 1988\end{array}$ \\
\hline & $\begin{array}{l}\text { Performance } \\
\text { Objectives }\end{array}$ & $\begin{array}{l}\text { Wilber, } 1948 \\
\text { Almost all authors have focused on } \\
\text { objectives }\end{array}$ \\
\hline $\begin{array}{l}\text { Intellectual } \\
\text { Processes }\end{array}$ & & $\begin{array}{l}\text { Sarapin and Starkweather, } 1981 \\
\text { Maley, } 1982 \\
\text { Moss, } 1987 \\
\text { Hatch, } 1988\end{array}$ \\
\hline Social & & $\begin{array}{l}\text { Pytlik, } 1981 \\
\text { Wright, } 1988\end{array}$ \\
\hline Personal & & $\begin{array}{l}\text { Maley, } 1973 \\
\text { Mentioned by: } \\
\text { Sarapin and Starkweather, } 1981 \\
\text { Maley, } 1982 \\
\text { Moss, } 1987\end{array}$ \\
\hline
\end{tabular}

the vocational educators. This association is apparent in the sequence of curriculum books which prescribed task analysis and followed Allen's (1919) original book (Selvidge, 1923; Selvidge and Fryklund, 1946; Fryklund, 1956 and 1970). Today, current texts about task analysis have strong ties to the ideas which Bobbitt outlined in 1918. Moreover, many industrial arts, soon to be technology, educators were exposed to task analysis as the primary method of curriculum planning for the field. The books by Selvidge and Fryklund emphasized that the task analysis methods were to be used for industrial arts curriculum planning with only the admonition to add more projects of a general education nature.

Some industrial arts/technology educators have identified a difficulty with task analysis as an appropriate prescriptive theory for curriculum planning in industrial arts/technology education. Lux created a reaction to his pronouncements against trade and job analysis in a 1979 editorial, causing some industrial arts educators to line up on opposite sides of the fence. The most frequently suggested alternative to the 
technical task analysis curriculum design, however, is the technical systems analysis curriculum design. Fully introduced to the industrial arts/technology education community by Towers, Lux, and Ray (1966) in their curriculum plans for industrial technology education, this design remains as technical and linear as task analysis. Using systems theory, industrial arts/technology educators were to identify the system of analysis and break down the component parts of the inputs, processes, and outputs in order to identify content for the subject matter. This kind of curriculum design is frequently recommended (Witherspoon, 1976; Ritz, 1980; Schwerkolt and Spontelli, 1987; Wescott, 1988; Jones, 1988; and Bjorklund, 1988) as a generic curriculum planning process for all curriculum assumptions, orientations, or designs. Using this design produces a focus on processes which are not very different from tasks.

In addition to the two methods of content analysis which have been developed by industrial arts/technology educators, almost all of those in industrial arts/technology education who offer curriculum advice (see Table 4 for an early work on this topic) utilize another aspect of the technical curriculum design, the structuring of the curriculum by some form of a performance objective. This popular and often mandated procedure further serves to reduce the complexity of curriculum to an observable behavior, omitting, by default, the attempt to instill values and the complexity which would relate to the social or personal curriculum designs.

It is interesting that this technical design is not viewed as a potential barrier to planning academic, intellectual processes, social, and personal curriculum and that it is widely endorsed. It may be that the nature of technology education and the teachers and teacher educators within the field causes a subconscious gravitation to the technical curriculum design (Zuga, 1987). It may be that the reductionism of the technical design provides a straightforward set of rules and procedures which simplify the complexities of curriculum planning and, therefore, simplify the teaching about planning curriculum. It may be that teachers and teacher educators have used forms of curriculum planning which are recommended by state and local education agencies. It may also be that as specialists in technology education, teachers and teacher educators are not prepared as curriculum specialists and are not aware of alternatives.

The technical curriculum design is by far the dominant design in technology education today. Even those who attempt to suggest alternatives ultimately employ a technical design. Therefore, although alternative curriculum designs are suggested, few are fully described.

Attempts at the Intellectual Processes Design. The intellectual processes design appears to be a curriculum design which is capturing selected technology educators' imaginations. However, it is not one which they readily identify as an intellectual processes design. In fact, most of the authors refer to this design as student- or learner-centered (personal). After designating ideas as learner-centered, explanations of what they mean, in view of the categories of curriculum designs, are best described as intellectual processes designs. Sarapin and Starkweather (1981) and Moss (1987) clearly take the path of introducing a new direction for the field as learner-centered and continue by recommending that curriculum planners identify intellectual processes which should be taught, create activities which students would like with those processes, and plan curriculum and instruction. By identifying the processes first, the authors are creating a design which focuses on those processes. The learner-centeredness of the design appears only as a slight afterthought when the educator selects activities that students will like. Maley (1982) does not place the personal element of the design as an afterthought; instead, he indicates that it is a factor equal to the intellectual processes and content (academic).

Unfortunately, current curriculum textbooks for technology education are lacking. This has caused authors to attempt to get across all of their ideas in one short article. Moreover, few in technology education have tried to describe a curriculum design and to operationalize that design into a prescriptive set of directions which are intelligible and easy to follow. Another of the difficulties in categorizing curriculum recommendations has been the lack of clarity of the authors. This may very well be caused by the lack of a framework which is known to technology educators for designing curriculum. These may also be some of the reasons for the confusion of the intellectual processes design.

The most promising outline of an intellectual processes curriculum design comes in a recent yearbook of the Council on Technology Teacher Education (CTTE). Hatch (1988) has attempted to define a problem solving approach to technology education. In his chapter of the yearbook, he begins with a problem solving focus by outlining the steps of problem solving and by selecting technology education content to fit the desired ends of teaching problem solving.

The Elusive Personal Curriculum Design. Several technology educators recommend personal curriculum designs. Selected goals of technology education indicate a personal design as a viable choice. As we have already observed, however, authors specify a personal design but fail to follow through with an adequate description and operationalization of the design. Sarapin and Starkweather (1981), Maley (1982), and Moss (1987) all seemed to be indicating the need for a personal curriculum design. Unfortunately, their papers did not describe one. The literature reflects a desire of technology educators to develop a personal curriculum design, but there is a lack of information about implementing such a design. 
The only contemporary example of a personal design was presented by Maley in 1973 as a part of The Maryland Plan. Within this program, students have the ability to select personally relevant activities in the context of industrial arts as well as their own approach to industrial arts; for example, the anthropological or the research and development approach. Essentially, traditional project work, a personal design element, was included in this program which sought to change the emphasis of traditional industrial arts.

It is interesting that a field which has staked its reputation on project work now has a lack of information for teachers about ways to implement such activity through technology education. Perhaps because of the history of the subject matter, industrial arts/technology educators are experts on this design and need very little help.

An Academic Design for Technology Education. Interest in technology as a discipline and the translation of that discipline in technology education classes has sparked an effort to identify and operationalize an academic curriculum design. An attempt to introduce an academic design appeared with the introduction of a taxonomy of technology by DeVore (1964). Early work in technology education by DeVore was focused on identifying appropriate curriculum, and his suggestions involved creating taxonomies which were similar to the taxonomies used in the sciences in order to categorize the species of life. His reporting on the idea of taxonomies has been discontinued in the literature but employed by others in a variety of forms. The results of the systems analysis pursued by Towers, Lux, and Ray (1966) were listed in the form of a taxonomy. They created a taxonomy of the processes which were identified through the analysis of inputs, processes, and outputs. A recent initial attempt at creating a conceptual taxonomy was shared by McCrory (1980) in a discussion about technology education as a discipline. His position clearly called for and applied an academic curriculum design. Maley (1982) has listed content as one of the three factors in his curriculum planning design. Unfortunately, Maley does not explain how to identify and organize content. Recently, two chapters of the 1988 Council on Technology Teacher Education (CTTE) yearbook used the basis of an academic design to discuss a conceptual and an interdisciplinary approach to teaching technology education. Yost (1988) discussed the identification of concepts, a very different approach than the technical design with task analysis, system analysis, and performance objectives at its base. Zuga (1988) introduced a popular curriculum process called webbing in order to identify the relationships between subjects. Webbing has been used for many years by elementary educators in order to identify subject content.

The recent emphasis on technology as a discipline, perhaps fueled by the contemporary emphasis on academic rationalism in education, has created an interest in the academic design among technology educators. This is a new and growing trend. Industrial arts/technology education is moving from hand tool instruction to an organized study of industry and technology. This change creates a need for members of the field to identify means of operationalizing an academic curriculum design.

The Ephemeral Social Design. There are few examples of social curriculum design for technology educators, despite the emphasis on the social goals of technology education. Many of the technical designs include categories which are referred to as social impacts, but they are ill-conceived and provide little direction to the teacher as to how to implement curriculum and instruction about social issues. One example by Pytlik (1981) attempted to focus on the social design and demonstrated, through example, how teachers might proceed to implement a social design in technology education. Pytlik recommended an interplay between a content structure of technology education and social issues. In his article, he recommended that curriculum planners use a structure of technology which has incorporated both technical concepts and an historical framework. Through this structure, topics were identified and operationalized so that the main emphasis in the classroom became a focus on social issues. Wright (1988) also attempted to focus on the social goals of technology education by identifying content and selecting appropriate social problems and activities to complement the content.

\section{A Framework for Curriculum Planning in Technology Education}

Traditional curriculum advice for industrial arts/technology education has been a variation of the technical curriculum design. Only recent literature has revealed an effort to introduce and operationalize curriculum designs which are inclusive of most of the five categories of curriculum. This effort is most likely the result of the change in the goals of technology education. The problems technology educators are facing in making this change are the preponderance of and reductionism in the technical design, the lack of preparation in curriculum studies, and the difficulty of operationalizing directions for implementing the other categories of curriculum design.

As technology education or any subject matter evolves, the goals of that subject matter begin to show a different emphasis. When an emphasis on content changes, educators must examine their practices with respect to curriculum and instruction and determine if their practices are compatible with the new 
goals of the subject matter. If curriculum and instruction practices are not compatible with the goals, then the implementation of intended goals may not take place.

How we determine the content of the curriculum in technology education will influence students' experiences in the classroom. If we select a series of social problems, a list of technical processes, a structure of critical thinking and problem solving skills, a taxonomy of concepts of technology, or allow students to selected technology-related problems which are significant to them, then the curriculum as a plan and as taught will appear to be different in each case. This difference will also appear in the way in which we analyze technology for the purpose of creating curriculum.

At present five categories of goals for technology education exist. Even with this variety of goals, we appear to be stressing one design of curriculum, a technical design, which has two primary methods of analyzing content, task analysis and systems analysis. Both of these methods tend to yield overt behaviors or processes which become the basis of the content for technology education curriculum. With current practices, it appears to be difficult for teachers to implement the variety of technology education goals which are prescribed for contemporary technology education.

In order to teach teachers about curriculum designs and processes, frameworks for analysis such as the one used in this paper could be employed. Ultimately, we would begin to address some of the complexities of curriculum planning instead of reducing it to a single process which may not be adequate for implementing all of the goals or intentions of technology education. The following is a framework which could serve to guide the creation of alternative curriculum planning models (see Table 5).

Teacher educators need to take the responsibility for initiating an examination and possible revision of what is taught to teachers with respect to curriculum. It is apparent that teachers employ a technical design for the purpose of creating curriculum documents for local, state, and national education agencies which require those designs and often employ quite different curriculum processes for their own purpose, teaching. Teacher educators are not addressing the most important part of a teacher's work, designing appropriate curriculum. Teacher educators need to continue to identify both teachers' curriculum planning practices and means of teaching curriculum planning for teachers which will improve teachers' abilities to implement the goals of technology education.

Table 5

Framework for Curriculum Planning Models

\begin{tabular}{llll}
\hline Design & $\begin{array}{l}\text { Goals and } \\
\text { Purposes }\end{array}$ & $\begin{array}{l}\text { Content } \\
\text { Source }\end{array}$ & $\begin{array}{l}\text { Structuring } \\
\text { Elements }\end{array}$ \\
\hline Academic & $\begin{array}{l}\text { Transmit cultural } \\
\text { heritage }\end{array}$ & $\begin{array}{l}\text { Constructs and } \\
\text { concepts }\end{array}$ & Taxonomies \\
Technical & $\begin{array}{l}\text { Develop } \\
\text { occupational } \\
\text { proficiency }\end{array}$ & $\begin{array}{l}\text { Observable } \\
\text { behaviors }\end{array}$ & Task analyses \\
Intellectual & $\begin{array}{l}\text { Improve thinking } \\
\text { Processes }\end{array}$ & $\begin{array}{l}\text { Cognitive } \\
\text { processes }\end{array}$ & $\begin{array}{l}\text { Problem solving } \\
\text { and trouble- } \\
\text { shooting } \\
\text { processes }\end{array}$ \\
Solving abilities & Reconstruct or & $\begin{array}{l}\text { Societal needs or } \\
\text { successful work } \\
\text { behaviors }\end{array}$ & $\begin{array}{l}\text { Social problems } \\
\text { or work } \\
\text { adjustment skills }\end{array}$ \\
& adapt to society & Student & Student research \\
Personal & Motivate & subject context & and projects \\
& personal interest & & \\
\hline
\end{tabular}

\section{References}

Allen, C. R. (1919). The instructor, the man, and the job. Philadelphia, PA: Lippencott. 
Bame, E. A. \& Miller, C. D. (1980). Philosophical views. Journal of Industrial Teacher Education, 18(1), 14-21.

Bjorklund, L. R. (1988). Interpretation of industry approach. In W. H. Kemp \& A. E. Schwaller, (Eds.) Instructional Strategies for Technology Education, 37th Yearbook of the Council on Technology Teacher Education. Mission Hills, CA: Glencoe.

Bobbitt, F. (1918). The curriculum. New York: Houghton-Mifflin.

Bollinger, E. W., \& Weaver, G. G. (1955). Trade analysis and course organization for shop teachers. New York: Pitman.

Commission on the Reorganization of Secondary Education (1918). Cardinal principles of secondary education. Bulletin No. 35. Washington, D. C. : Government Printing Office.

DeVore, P. W. (1964). Technology as an intellectual discipline. Bulletin No. 5, Washington, D.C.: American Industrial Arts Association.

Educational Policies Commission. (1937). The unique function of education in American democracy. Washington, D. C. : National Education Association.

Eisner, E. W. (1979). The educational imagination. New York: Macmillan.

Eisner, E. W., \& Vallance, E. (1974). Conflicting conceptions of curriculum. Berkeley, CA: McCutchan.

Fryklund, V. C. (1956). Analysis techniques for instructors. Milwaukee, WI: Bruce.

Fryklund, V. C. (1970). Occupational analysis: Techniques and procedures. New York: Bruce.

Hatch, L. (1988). Problem solving approach. In W. H. Kemp \& A. E. Schwaller, (Eds.) Instructional Strategies for Technology Education, 37th Yearbook of the Council on Technology Teacher Education. Mission Hills, CA: Glencoe.

Jones, R. E. (1988). Integrating the systems of technology approach. In W. H. Kemp \& A. E. Schwaller, (Eds.) Instructional Strategies for Technology Education, 37th Yearbook of the Council on Technology Teacher Education. Mission Hills, CA: Glencoe.

Joyce, B. R. (1980). Learning how to learn. Theory and Practice, 19(1), 15-27.

Lux, D. G. (1979). Trade and job analysis--- The scourge of industrial arts. School Shop, 38(7), 2.

Lux, D. G. \& Ray, W. E. (1970). The World of Construction. Bloomington, IL: McKnight \& McKnight.

Lux, D. G. \& Ray, W. E. (1971). The World of Manufacturing. Bloomington, IL: McKnight \& McKnight.

Maley, D. (1973). The Maryland plan. New York: Bruce.

Maley, D. (1982). Putting theory into practice. Man, Society, and Technology, 41(8), 3-11.

McCrory, D. L. (1980). Content structure for technology education: Toward new curricula for the 1980's. The Journal of Epsilon Pi Tau, 6(2), 27-34.

McNeil, J. D. (1977). Curriculum: A comprehensive introduction. Boston, MA: Little-Brown.

Moss, J., Jr. (1987). Technology education: Subject-or student-content? The Journal of Epsilon Pi Tau, $13(1), 40-43$.

Newkirk, L. V., \& Johnson, W. H. (1948). The industrial arts program. New York: Macmillan.

Ornstein, A. C., \& Hunkins, F. P. (1988). Curriculum: Foundations principles, and issues. Englewood Cliffs, NJ: Prentice Hall.

Pytlik, E. C. (1981). Technology education and human values: A course for high school students. The Journal of Epsilon Pi Tau, 7(2) 36-42.

Ritz, J. M. (1980). Systematic curriculum development for industrial education. Man, Society, and Technology, 40(1), 11-13.

Sarapin, M. I., \& Starkweather, K. N. (1981). Curriculum development: Placing the learner at the center of the instructional process. The Journal of Epsilon Pi Tau, 7(1), 60-6.

Saylor, J. G., Alexander, W. M. \& Lewis, A. J. (1981). Curriculum planning: For better teaching and learning. New York: Holt, Rinehart, and Winston.

Schubert, W. H. (1986). Curriculum: perspective, paradigm, and possibility. New York: MacMillan.

Schwerkolt, E. A. \& Spontelli, C. (1987). A practical model for developing instructional systems. The Journal of Epsilon Pi Tau, 13(2), 51-56.

Selvidge, R. W. (1923). How to teach a trade. Peoria, IL: Manual Arts Press.

Selvidge, R. W. \& Fryklund, V. C. (1946). Principles of trade and industrial teaching. Peoria, IL: Manual Arts Press.

Technical Foundation of America. (undated). Industry and technology education: A guide for developing contemporary industrial arts/technology education curricula. Lansing, IL.

Towers, E. R., Lux, D. G. \& Ray, W. E. (1966). A rationale and structure for industrial arts subject matter. (ERIC Document Reproduction Service No. ED 013 955)

Tyler, R. W. (1949). Basic principles of curriculum and instruction. Chicago, IL: University of Chicago.

Warner, W. E. (1928). Policies in industrial arts education. Columbus, OH: The Ohio State University Press. 
Wescott, J. W. (1988). Teaching concepts: A challenge for technology educators. The Technology Teacher, 48(1).

Wiles, J. \& Bondi, J. C. (1984). Curriculum development: A guide to practice. Columbus, OH: Bell and Howell.

Wilber, G. O. (1948). Industrial arts in general education. Scranton, PA: International Textbooks.

Wilber, G. O. \& Pendered, N. C. (1967). Industrial arts in general education. Scranton, PA: International Textbook.

Witherspoon, E. L. (1976). Effecting curriculum change in industrial arts. Man, Society, and Technology, 35(7), 207-9.

Woodward, C. M. (1898). Manual training in education. New York: Charles Scribner \& Sons.

Wright, J. R. (1988). Social/cultural approach. In W. H. Kemp \& A. E. Schwaller, (Eds.) Instructional Strategies for Technology Education, 37th Yearbook of the Council on Technology Teacher Education. Mission Hills, CA: Glencoe.

Yost, C. E. (1988). Conceptual learning approach. In W. H. Kemp \& A. E. Schwaller, (Eds.) Instructional Strategies for Technology Education, 37th Yearbook of the Council on Technology Teacher Education. Mission Hills, CA: Glencoe.

Zuga, K. F. (1987). Trapped in a technocratic ideology. Paper presented at the American Educational Research Association Conference in Washington, D. C. (ERIC Document Reproduction Service No. ED 282 994)

Zuga, K. F. (1988). Interdisciplinary approach. In W. H. Kemp \& A. E. Schwaller, (Eds.) Instructional Strategies for Technology Education, 37th Yearbook of the Council on Technology Teacher Education. Mission Hills, CA: Glencoe. 